\title{
Sistematik Filogenetik Isolat-isolat Kapang Indigenous Indonesia sebagai Entomopatogen Kutu Sisik (Lepidoshapes beckii Newman) Hama Tanaman Jeruk
}

\author{
Phylogenetic Systematics of Indonesian Indigenous Mould Isolates as Entomopathogen of \\ Purple Scale Insect (Lepidoshapes beckii Newman) Pest of Citrus Plants \\ Suharjono $^{1 *}$, Agung P.W. Marhendra ${ }^{1}$, Anang Triwiratno ${ }^{2}$, Susi Wuryantini', dan Lina \\ Oktavia $\mathbf{R}^{1}$ \\ ${ }^{1}$ Jurusan Biologi, FMIPA, Universitas Brawijaya, Malang, Jl Veterang 169 Malang 65145 \\ ${ }^{2}$ Balai Penelitian Tanaman Jeruk dan Buah Subtropika (Balitjestro), Batu, Jawa Timur \\ E-mail: calistus@brawijaya.ac.id *Penulisuntuk korespondensi
}

\begin{abstract}
Citrus fruits constitute a basic agricultural product in many countries. They are a source of national income, empowering labor market in rural zones and those surrounding urban areas, and in addition to being an important part of the diet. Insects are common problems to planting of citrus. Purple Scale, Lepidosaphes beckii (Newman) is one of the destructive insect pests of citrus worldwide. The control of purple scale insects in citrus utilizes native natural enemies including pathogens. Most known species of mould are pathogens of purple scale insect of citrus. The objective of this research was to study phylogenetic systematics of Indonesian indigenous mould isolates as pathogen on purple scale insect (Lepidoshapes beckii Newman) pest of citrus plants. Seven mould isolates derived from Purworejo, Brastagi, and Poncokusumo were showed pathogenic on purple scale insect. The fungal isolates were cultured on PDA. The DNA of fungal material was isolated with Kit Prepman Ultra (Applied Biosystems). Nuclear ribosomal Large Subunit 28S rDNA (LSU) was amplified using primers ITS1 and ITS4. Products of PCR were purified and sequenced. Based on the 28S rDNA sequence, the result was showed that isolate of PW ASG D4 was related to Gibberella moniliformis dx-12, PC ORG D4 was related to Gibberella sp. 1893, PW ASG D2 was related to Gibberella moniliformis BZ070101, PW LB D2 was related to Gibberella moniliformis 52, BRS D22 was related to Fusarium oxysporum DC-1-67, PWRJ I D4 was related to Fusarium culmorum SQ070108, and BRS D23 was related to Aschersonia sp. Ag-11.
\end{abstract}

Key words: Entomopathogen, mould, purple scale insect, phylogenetic, 28S rDNA

\begin{abstract}
Abstrak
Buah jeruk merupakan produk pertanian sebagai sumber devisa, penyerap tenaga kerja, dan sebagai bahan pangan yang penting di banyak Negara. Berbagai insekta di antaranya kutu sisik coklat Lepidosaphes beckii (Newman) menjadi hama perusak pada tanaman jeruk di seluruh dunia. Pengendalian kutu sisik coklat pada tanaman jeruk dapat menggunakan kapang patogen indigenus sebagai musuh alami. Tujuan penelitian ini untuk mempelajari sistematik filogenetik tujuh isolat kapang indigenus Indonesia yang berasal dari Purworejo, Brastagi dan Poncokusumo yang patogenik pada kutu sisik coklat hama pada tanaman jeruk. Isolat-isolat kapang dibiakkan pada medium PDA dan DNA kromosom inti diisolasi dengan Kit Prepman Ultra (Applied Biosystems). Subunit besar 28S rDNA ribosom dari DNA inti diamplifikasi dengan primer ITS1 dan ITS4 kemudian amplikon dipurifikasi dan disekuensing. Berdasarkan sekuen 28S rDNA menunjukkan bahwa isolat PW ASG D4 berkerabat dengan Gibberella moniliformis dx-12, PC ORG D4 berkerabat dengan Gibberella sp. 1893, PW ASG D2 berkerabat dengan Gibberella moniliformis BZ070101, PW LB D2 berkerabat dengan Gibberella moniliformis 52, BRS D22 berkerabat dengan Fusarium oxysporum DC-1-67, PWRJ I D4 berkerabat dengan Fusarium culmorum SQ070108, dan BRS D23 berkerabat dengan Aschersonia sp. Ag-11.
\end{abstract}

Kata kunci: Kapang, entomopatogen, kutu sisik coklat, filogenetik, 28SrDNA 


\section{Pendahuluan}

Buah jeruk merupakan produk pertanian yang penting di banyak negara karena sebagai sumber devisa, penyerap tenaga kerja, dan sebagai bahan pangan (Morton, 2001). Buah tersebut sebagai komoditas terpenting di Indonesia setelah pisang dan mangga. Sampai saat ini produktivitas jeruk di Indonesia masih rendah yaitu berkisar 8,6-15 ton/ha/tahun dan pengembangannya masih jauh tertinggal dengan negara lain (Sistim Informasi Manajemen Pembangunan di Perdesaan, BAPPENAS, 2007). Produktivitas yang rendah ini antara lain disebabkan oleh adanya serangan kutu sisik coklat (Lepidosaphes beckii Newman) yang saat ini merupakan hama utama pada tanaman jeruk di berbagai negara (Futch et al., 2001; Meekes, 2001, Meekes et al., 2002; Triwiratno, 2004; Triwiratno dan Yunimar, 2005; Anonim, 2007; Dolinski dan Lacey, 2007). Nimpa dan kutu dewasa hama tersebut menghisap cairan dari daun, buah, cabang, dan batang tanaman jeruk; menyebabkan khlorosis dan gugurnya daun, pemasakan tidak sempurna dan gugurnya buah, cabang kering dan mati atau bahkan matinya tanaman (Anonim, 2007).

Beberapa jenis kapang entomopatogen seperti Beauveri bassiana, Metarhizium anisopliae (Santra, 2004), Hypocrellal Aschersonia sp. (Meekes et al., 2002, Chaverri et al., 2008), Gibberella dan Fusarium sp. (Barrag'an, et al., 2004) dapat menginfeksi kutu sisik coklat. Konidia kapang entomopatogen tumbuh menembus kutikula menyebabkan kutikula pecah dan kematian kutu sisik (Liu et al., 2006; Meekes, 2001 cit. Chaverri et al., 2008). Kapang tersebut sangat sesuai sebagai agen pengendalian serangga hama penghisap tanaman (Hemiptera) (Dolinski dan Lacey, 2007), mudah dibiakkan, dan spesifik. Fungi entomopatogen menghasilkan metabolit sekunder yang bersifat insektisidal terhadap kutu sisik, yaitu destruxins cyclohexadepsipeptides A4 dan A5 serta Ascherxanthone A yang merupakan senyawa depsipeptida (Krasnoff dan Gibson, 1996; Isaka et al., 2005; Ganassi et al., 2008).

Beberapa isolat kapang indigenous Indonesia menunjukkan patogenisitas yang tinggi terhadap kutu sisik coklat (Suharjono et al., 2008). Identifikasi isolat-isolat kapang tersebut berdasarkan karakter fenotip hasilnya tidak akurat serta tidak mencerminkan hubungan filogeni dan evolusi. Data sekuen 28S rDNA saat ini digunakan sebagai dasar identifikasi taksa fungi dalam sistem hirarki yang mencerminkan hubungan kekerabatan dan evolusinya (Shenoy et al., 2007). Oleh karena itu penelitian ini bertujuan untuk identifikasi spesies entomopatogen tersebut berdasarkan sekuen 28S rDNA.

\section{Metode Penelitian}

\section{Isolat-Isolat Kapang Uji}

Kapang yang digunakan dalam penelitian ini meliputi tujuh isolat indigenous Indonesia sebagai patogen kutu sisik coklat (Lepidosaphes beckii Newman) hama pada tanaman jeruk di Purworejo, Jawa Tengah; Brastagi, Sumatera Utara; dan Poncokusumo, Jawa Timur (Tabel 1). Semua isolat kapang merupakan hasil isolasi monospora yang ditumbuhkan dalam medium Potato Dextrose Agar (PDA).

\section{Isolasi DNA Kapang}

Isolasi DNA setiap isolat kapang dilakukan dengan menggunakan Kit Prepman Ultra (Applied Biosystems). Hifa kapang dari medium PDA umur tiga hari dimasukkan ke dalam tabung eppendorf yang berisi $200 \mu \mathrm{K}$ Kit Prepman Ultra, kemudian divorteks selama 10-30 menit. Suspensi dipanaskan pada suhu $100^{\circ} \mathrm{C}$ selama 10 menit kemudian disentrifugasi pada kecepatan 16.000xg selama tiga menit. Supernatan DNA dipindahkan ke dalam tabung eppendorf yang baru dan disimpan pada suhu $4^{\circ} \mathrm{C}$.

\section{Amplifikasi dan Sekuensing 28S rDNA}

Amplifikasi dan sekuensing 28S rDNA kapang dilakukan menurut Fang et al., (1992). Suspensi DNA hasil isolasi dilakukan PCR menggunakan Kit LA Tag (TAKARA) dengan primer ITS1 (5'-TCCGTAGGTGAACCTGC GG-3') dan ITS4 (5'-TCCTCCGCTTATTGAT ATGC-3'). Reaksi PCR menggunakan komposisi senyawa $25 \mathrm{mM} \mathrm{MgCl} 25 \mu \mathrm{l}, 2,5 \mathrm{mM}$ dNTP mix $4 \mu \mathrm{l}, 10 \times$ buffer $5 \mu \mathrm{l}$, LA Tag $0,25 \mu \mathrm{l}, 10 \mu \mathrm{M}$ primer ITS1 $2 \mu \mathrm{l}, 10 \mu \mathrm{M}$ primer ITS4 $2 \mu \mathrm{l}$, $\mathrm{ddH}_{2} \mathrm{O} 29,75 \mu \mathrm{l}$, template $(<1 \mu \mathrm{g}) 2 \mu \mathrm{l}$. Program 
PCR untuk amplifikasi DNA tersebut dilakukan pada suhu denaturasi awal $95^{\circ} \mathrm{C}$ selama 3 menit, dilanjutkan 30 siklus (suhu denaturasi $94^{\circ} \mathrm{C}$ selama 30 detik, annealing $55^{\circ} \mathrm{C}$ selama 20 detik, dan ekstensi $72^{\circ} \mathrm{C}$ selama 1 menit) serta ekstensi akhir pada suhu $72^{\circ} \mathrm{C}$ selama 5 menit. Amplikon DNA hasil PCR sebanyak $50 \mu \mathrm{l}$ dielektroforesis menggunakan gel agarosa $1 \%$. Amplikon DNA hasil PCR dipurifikasi menggunakan Gene AID Gel.

Amplikon murni 28S rDNA dilakukan PCR cycle sequencing menggunakan Kit Big Dye V3.1 (Applied Biosystems). Reaksi PCR cycle sequencing menggunakan komposisi senyawa Big Dye V3.1 $1 \mu \mathrm{l}, 5 \times$ buffer $2 \mu 1,1,6$ $\mu \mathrm{M}$ primer ITS1/primer ITS4 $2 \mu 1$, template (5$20 \mathrm{ng}) 2 \mu \mathrm{l}, \mathrm{ddH}_{2} \mathrm{O} 3 \mu \mathrm{l}$. Sampel hasil PCR cycle sequencing ditambah $10 \mu \mathrm{l}$ air bebas DNA dan RNA, kemudian ditambahkan $2 \mu$ l EDTA 125 $\mathrm{mM}, 2 \mu \mathrm{l}$ natrium asetat $3 \mathrm{M}$ dan $50 \mu \mathrm{l}$ etanol absolut. Sampel diinversi sebanyak empat kali dan diinkubasi pada suhu ruang selama 15 menit. Sampel disentrifugasi dengan kecepatan 5.000xg selama 30 menit. Supernatan dibuang, kemudian pelet ditambah dengan $70 \mu 1$ etanol $70 \%$. Sampel disentrifugasi dengan kecepatan 3.000xg selama 15 menit dan supernatan dibuang. Sisa etanol $70 \%$ dihilangkan dengan dispindown, kemudian dikeringkan dalam vakum desikator selama 10 menit. Sampel dielusi dengan $12 \mu \mathrm{l}$ air bebas DNA dan RNA, kemudian dipanaskan dengan heat block digital pada suhu $42^{\circ} \mathrm{C}$ selama lima menit dan ditapping perlahan setiap dua menit. Sampel kemudian dispindown dan disekuensing menggunakan Gene Cycler Sequencer 3130 XL Applied Biosystems.

Sekuen semua isolat kapang bersama sekuen spesies acuan dialignment menggunakan program ClustalX. Pohon filogeni dikonstruksi dengan menggunakan program PHYLIP (Phylogeny Inference Package). Pohon filogeni diinferensi dengan menggunakan metode Neighbour-Joining, sedangkan jarak evolusi dianalisis menurut model Jukes-Cantor (Saitou dan Nei, 1987 cit. Kim et al., 2000; Sembiring, 2002).

\section{Hasil dan Pembahasan}

Hasil penelitian Suharjono et al., (2008) menunjukkan bahwa isolat kapang dari Purworejo (PW ASG D2, PW LB D2, dan PWRJ I D4) dan Brastagi (BRS D23) memiliki patogenisitas paling tinggi terhadap imago Lepidoshapes beckii. Isolatisolat kapang tersebut secara genetik menunjukkan berbeda spesies (Gambar 1). Berdasarkan sekuen parsial 28S rDNA, isolat PW ASG D2 berkerabat dekat dan memiliki nilai similaritas $100 \%$ dengan Gibberella moniliformis BZ070101, PW LB D2 berkerabat dekat dan similaritasnya $100 \%$ dengan Gibberella moniliformis52, dan PWRJ I D4 berkerabat dekat dan memiliki similaritas 99,8\% dengan Fusarium culmorum SQ070108, yaitu satu nukleotida yang berbeda dari 495 nukleotida. Isolat kapang BRS D23 berkerabat dekat dan memiliki nilai similaritas 89,74\% dengan Aschersonia sp. Ag-11.

Tiga isolat kapang: PW ASG D4, PC ORG D4, dan BRS-D22 memiliki potensi patogenisitas yang rendah terhadap kutu sisik coklat (Suharjono et al., 2008). Berdasarkan analisis filogenetik sekuen parsial 28S rDNA, bahwa isolat PW ASG D4 berkerabat dekat dan memiliki nilai similaritas 98,49\% dengan Gibberella moniliformis dx-12, yaitu tujuh nukleotida yang berbeda dari 464 nukleotida. Isolat PC ORG D4 berkerabat dekat dan memiliki nilai similaritas $100 \%$ dengan Gibberella sp. 1893. Isolat BRS-D22 berkerabat dekat dan memiliki similaritas $98,47 \%$ dengan Fusarium oxysporum DC-1-67, yaitu tujuh nukleotida yang berbeda dari 458 nukleotida.

Tabel 1. Isolat Kapang Entomopatogen.

\begin{tabular}{|c|c|}
\hline Isolat & Daerah Asal \\
\hline PW ASG D4 & "Purworejo, Jawa Tengah \\
\hline PW ASG D2 & Purworejo, Jawa Tengah \\
\hline PWRJ I D4 & Purworejo, Jawa Tengah \\
\hline PW LB D2 & Purworejo, Jawa Tengah \\
\hline BRS D22 & Brastagi, Sumatera Utara \\
\hline BRS D23 & Brastagi, Sumatera Utara \\
\hline PC ORG D4 & Poncokusumo, Jawa Timur \\
\hline
\end{tabular}




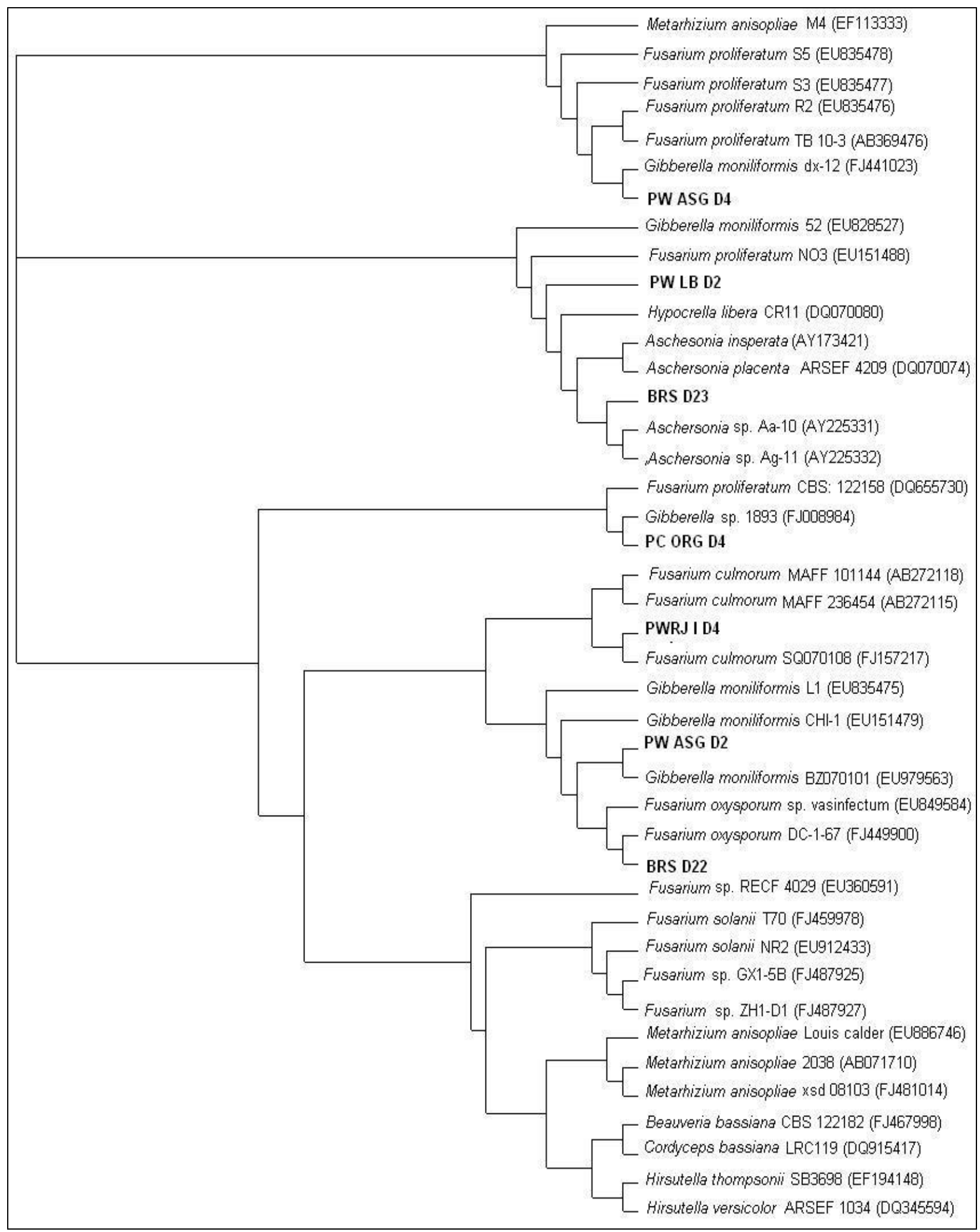

Gambar 1. Pohon filogeni yang dibuat berdasarkan algoritma Neighbour-joining yang menunjukkan hubungan antara strain acuan dan isolat kapang entomopatogen pada kutu sisik coklat (Lepidoshapes beckii Newman) atas dasar sekuen parsial 28S rDNA. 
Isolat PW LB D2 satu kelompok dan berkerabat dekat dengan PC ORG D4, tetapi kekerabatannya jauh dengan kelima isolat lainnya. Sekuen ribosomal DNA digunakan untuk identifikasi dan menentukan hubungan filogenetik organisme sampai taksa spesies (Drancourt et al., 2000; Goto et al., 2000; JunZhi et al., 2005; Shenoy et al., 2007). Isolatisolat kapang entomopatogen yang menunjukkan hubungan filogenetik yang tinggi dan memiliki nilai similaritas sekuen 28S rDNA lebih dari 99\% dengan spesies acuan dapat dinyatakan sebagai satu spesies. Berdasarkan konsep spesies secara filogenetik dinyatakan bahwa organisme dalam satu spesies bila perbedaan sekuen DNA antara 0,2-1\% (Drancourt et al., 2000; Moncalvo, 2005 cit. Shenoy et al., 2007).

Isolat BRS-D23 secara filogeni dan evolusi berkerabat dekat dan satu kelompok dengan spesies anggota Genus Aschersonia, tetapi nilai similaritasnya rendah. Rendahnya nilai similaritas tersebut kemungkinan disebabkan kurang tepat dan kurang banyak spesies dari genus tersebut yang digunakan sebagai acuan. Oleh karena itu perlu dikaji lebih lanjut identifikasi isolat BRS-D23 dengan spesies acuan yang lebih banyak dari anggota genus tersebut. Menurut Henry et al. (2000) isolat-isolat yang memiliki nilai similaritas $100 \%$ dapat dinyatakan sebagai satu strain yang sama dan nilai similaritas $99 \%$ dinyatakan sebagai satu spesies yang sama, sedangkan nilai similaritas 89-99\% termasuk dalam genus yang sama. Berdasarkan hal tersebut dapat dinyatakan bahwa kedua isolat yang paling efektif yaitu isolat PW ASG D2 adalah spesies Gibberella moniliformis BZ070101 dan isolat BRS D23 adalah termasuk genus Aschersonia.

Identifikasi spesies kapang menggunakan sekuen 28S rDNA secara utuh lebih prediktif dan akurat, tetapi tidak efisien karena sekuen nukleotidanya terlalu panjang. Oleh karena itu, dikembangkan kajian identifikasi secara filogenetik berdasarkan berbagai bagian dari sekuen 28S rDNA antara lain bagian ITS (Internal Transcribed Spacer). Sekuen ITS 28S rDNA tersebut memiliki kurang lebih 600 nukleotida. Menurut Hebert dan Gregory (2005 cit. Shenoy et al., 2007) penggunaan karakter DNA saja tidak cukup untuk mendiskripsikan suatu spesies baru. Ternyata sekuen bagian ITS dari $28 \mathrm{~S}$ rDNA resolusinya kurang spesifik dan peka untuk divergensi spesies-spesies yang monofiletik. Oleh karena itu hasil identifikasi ini perlu diverifikasi dengan sistem identifikasi filogenetik yang lain dan identifikasi fenotipik (identifikasi polifasik) untuk menetapkan taksa dengan benar dan akurat (Jamal et al., 2009).

\section{Simpulan dan Saran}

\section{Simpulan}

Berdasarkan sekuen parsial daerah ITS pada 28S rDNA dengan nilai similaritas lebih dari 99\%, maka dinyatakan bahwa PW ASG D2 dan PW LB D2 merupakan anggota Spesies Gibberella moniliformis dan PWRJ I D4 anggota Spesies Fusarium culmorum. Isolat PC ORG D4 secara filogenetis merupakan anggota Spesies Gibberella sp.

\section{Saran}

Isolat-isolat kapang yang nilai similaritas kurang dari $100 \%$ perlu dianalisis klasifikasi secara filogenetik terhadap spesies-spesies acuan yang lebih banyak dari anggota genus yang sesuai untuk memastikan nama spesiesnya.

\section{Ucapan Terima Kasih}

Ucapan terima kasih disampaikan kepada Badan Litbang Departemen Pertanian Republik Indonesia yang telah membiayai penelitian dengan dana KKP3T. Ucapan terima kasih disampaikan juga kepada Kepala Balitjestro Batu yang telah memberikan batuan fasilitas untuk penelitian.

\section{Daftar Pustaka}

Anonim. 2007. Lepidosaphes beckii (Newman, 1869). http://www.itis.gov/servlet/SingleRpt/ RefRpt.

Barrag'an, A.T., Anaya, A.L., Alatorre, R. dan Toriello, C. 2004. Entomopathogenic Fungi from 'El Eden' Ecological Reserve, Quintana Roo, Mexico. Mycopathologia, 158: 61-71.

Chaverri, P., Liu, M. dan Hodge, K.T. 2008. A Monograph of the Genera Hypocrella, Moelleriella, and Samuelsia gen. nov. (Ascomycota, Hypocreales, Clavicipitaceae), and Their Aschersonia-like Anamorphs in the Neotropics. Studies in Mycology 60: 1-66. http://www. studiesinmycology.org. 
Dolinksi, C. dan Lacey, L.A. 2007. Microbial Control of Arthropods Pests of Tropical Tree Fruits. Neotrop. Entomol., 36 (2): 161-179.

Drancourt, M., Bollet, C., Carlioz, A., Martelin, R., Gayral, J.P. dan Raoult, D. 2000. 16S Ribosomal DNA Sequence Analysis of A Large Collection of Environmental and Clinical Unidentifiable Bacterial Isolates. J. Clin. Microbiol., 38 (10): 3623-3630.

Fang, G., Hammar, S. dan Grunet, R. 1992. A Quick and Inexpensive Methode for Removing Polysaccharides from Plant Genomic DNA. Biotechniques, 13: 52-56.

Futch, S.H., McCoy, C.W. dan Childers, C.C. 2001. A Guide to Scale Insect Identification. EDIS, University of Florida.

Ganassi, S., Cristofaro, A.D., Grazioso, P., Altomare, C., Logrieco, A. dan Sabatini, M.A. 2008. Detection of Fungal Metabolites of Various Trichoderma Species by The Aphid Schizaphis graminum. J. Compil. Entomol. Experiment. et Applic., 122: 77-86.

Goto, K., Omura, T., Hara, Y. dan Sadaie, Y. 2000. Application of the Partial 16S rDNA Sequence as an Index for Rapid Identification of Species in the Genus Bacillus. J. Gen. Appl. Microbiol., 46: $1-8$.

Henry, T., Iwen, P.C. dan Hinrichs, S.H. 2000. Identification of Aspergillus Species Using Internal Transcribed Spacer Regions 1 and 2. J. Clin. Microbiol., 38 (4): 1510-1515.

Isaka, M., Palasarn, S., Kocharin, K. dan Saenboonrueng, J. 2005. A Cytotoxic Xanthone Dimer from the Entomopathogenic Fungus Aschersonia sp. BCC 8401. J. of Natural Production, 68 (6): 945-946.

Jamal, Y., Muhamad, I., Atit, K. dan Andria, A. 2009. Keragaman Jenis Jamur Endofit pada Pandan Wangi (Pandanus amarylifolius) dan Aktivitas Antijamur Metabolit yang Diproduksinya. Biota, 14 (2): 81-86.

Jun-Zhi, Q., Zhi-Peng, H., Jie-Ru, P., Xue-Qin, X., YanPing, Z., Fang, F., Shao-Sheng, Z. dan Xiong, G. 2005. RAPD and Large Subunit Nuclear rDNA Sequence Analyses of the Entomogenous Fungus Aschersonia. Chinese J. of Agricultural Biotechnology, (2): 85-90.

Kim, S., Chun, J., Bae, K.J. dan Kim, Y. 2000. Polyphasic Assignment of an Aromatic-Degrading Pseudomonas sp. Strain Dj77 in the Genus Spingomonas as Spingomonas chungbukensis sp., nov. International J. of Systematic and Evolutionary Microbiology, 50: 1641-1647.
Krasnoff, S.B. dan Gibson, D.M. 1996. New Destruxins from the Entomopathogenic Fungus Aschersonia sp. J. of Natural Production, 59 (5): 485-489.

Liu, M., Chaverri, P. dan Hodge, K.T. 2006. A Taxonomic Revision of the Insect Biocontrol Fungus Aschersonia aleyroidis, its Allies with Stromata and their Hypocrella Sexual States. Mycologycal research, 110 (5): 537-554.

Meekes, E.T.M. 2001. Biological Control of Whiteflies with Entomopathogenic Fungi Tritrophic Interactions between Aschersonia spp. Bemisia argentifolii and Trialeurides vaporarium and Glasshouse Crops. Dissertation. Wagebingen University.

Meekes, E.T.M., Fransen, J.J. dan van Lenteren, J.C. 2002. Pathogenicity of Aschersonia spp. Against Whiteflies Bemisia argentifolii and Trialeurides vaporarium. J. of Invertebrate Pathology, 81 (1): $1-11$.

Morton, J. 2001. Orange Citrus cinensis. http://www.hort. purdue.edu/newcrop/morton/orange.html.

Santra, S.C. 2004. Aschersonia spp. host specificity. ENVIS Node on Environmental Biotechnology Department of Environmental Science, University of Kalyani. http://www.kuenvbiotech.org.

Sembiring, L. 2002. Sistematik Molekular, Petunjuk Praktikum. Laboratorium Mikrobiologi Fakultas Biologi Universitas Gadjah Mada, Yogyakarta.

Shenoy, B.D., Jeewon, R. dan Hyde, K.D. 2007. Impact of DNA Sequence-Data on the Taxonomy of Anamorphic Fungi. Fungal Diversity, 26: 1-54.

Sistim Informasi Manajemen Pembangunan di Perdesaan, BAPPENAS. 2007. JERUK (Citrus sp.). warintek.bantul.go.id/web.php?mod=basisdata $\&$ kat $=1 \&$ sub $=2 \&$ file $=44$.

Suharjono, Marhendra, A.P.W., Triwiratno, A. dan Wuryantini, S. 2008. Keanekaragaman dan Potensi Aschersonia sp. Entomopatogen Kutu Sisik (Lepidoshapes beckii) pada Tanaman Jeruk. Laporan Hasil Penelitian KKP3T.

Triwiratno, A. 2004. Teknologi Pengendalian Kutu Sisik/ Kutu Perisai (Lepidoshapes beckii Newman, Unapsis citri) pada Tanaman Jeruk. Balai Penelitian Tanaman Jeruk dan dan Buah Subtropika, Batu.

Triwiratno, A. dan Yunimar. 2005. Pengembangan Pemanfaatan Jamur Merah Aschersonia sp. Sebagai Entomopatogen Kutu Sisik pada Tanaman Jeruk. Balai Penelitian Tanaman Jeruk dan dan Buah Subtropika, Batu. 